\title{
AN ABNORMAL SAMPLE OF BUTTER FROM A CHESHIRE HERD OF COWS.
}

\author{
BY ALFRED SMETHAM, F.I.C.
}

(Read at the Meeting, May 5, 1909.)

THE following case furnishes another instance of the well-known fact that, under some conditions, even a herd of a considerable number of cows may yield abnormal butter.

A sample of butter, taken early in December, 1908, having been condemned as containing an admixture of foreign fat, a portion of it was, a month later, referred to me, with information from which it appeared improbable that adulteration had taken place. For comparative examination I obtained a sample of butter direct from the farm in Cheshire from which the suspected sample was originally supplied, and also, from the same farm, a sample of milk, from which I myself churned some butter. The three samples gave the following results:

\begin{tabular}{|c|c|c|c|}
\hline & $\begin{array}{c}\text { Original } \\
\text { Suspected Sample, } \\
\text { December } 3 \text {. } \\
\ldots \quad 18.8\end{array}$ & $\begin{array}{c}\text { Butter taken } \\
\text { at Farm, } \\
\text { January } 5 . \\
17 \cdot 9\end{array}$ & $\begin{array}{c}\text { Butter churned } \\
\text { from Afternoon Milk, } \\
\text { January } 8 . \\
17.9\end{array}$ \\
\hline & $44 \cdot 6$ & $39 \cdot 6$ & - \\
\hline
\end{tabular}

I understood that the cows still left in milk on January 8 were two barren cows, three late calvers, and about ten cows just going off milk and milked only in the morning. On January 11 I examined butter churned by myself from the mixed milk of all these cows, obtaining a Reichert-Wollny figure of 17.4. Two other analysts to whom the milk was forwarded found $17 \cdot 8$ and $17 \cdot 1$ respectively. Two further samples of butter churned in the ordinary way on the farm gave Reichert-Wollny figures of $18 \cdot 6$ and $18 \cdot 1$.

The farm, I should say at once, was a cheese-making farm, and, as it seemed to me probable that this case might be typical of other cases in Cheshire (where it is the custom when the cows are going off milk-and only then-to make butter instead of cheese), I thought it would be interesting to inquire further into the circumstances, and to this end I asked the owner of the cows for full particulars of his herd, mode of feeding, etc. The inquiry elicited the following facts :

At the time (the beginning of December) when the original sample of butter was taken there were fifty cows still in milk, but rapidly going off. Of these, forty had calved in February and March, eight in April, one in May, and one in June. As far. as recollection served, the suspected sample was made from a mixture of whey cream from the last cheeses and cream from the milk yielded after cheese-making had ceased, the two creams being mixed and churned together. So long as cheese was being produced (that is to say, up to the time just before the taking of this sample), the cows were fed with corn in addition to grass; and they were at that time in "fair" condition-that is to say, in about the same condition in which average cheesemaking herds in Cheshire would be at that time of year. When cheese-making ceased the corn was dropped, and the feed consisted of hay of somewhat inferior 
quality (ad libitum) and what grass the animals could get when they were turned out in the middle of the day. This change of diet was made because it was desired that the cows should "dry off." On February 7, learning that some of the cows had calved, I asked their owner to supply me with some of the milk from these, as well as from his barren cows and late calvers. By this time, it may be observed, the use of corn had been resumed, a mixture of equal parts of Indian corn meal, decorticated cotton-cake, and bran, being given, in addition to prime upland hay ad libitum. The milk from the freshly calved cows was obtained from two cross-bred dairy Shorthorns, which had been fifteen and sixteen days in milk, and were yielding from 26 to 28 quarts per day. The mixed corn, etc., given to these cows amounted to 6 to 8 pounds per head per day. In the same shed were one of the barren cows and two late calvers, being part of the five which yielded the milk of January 11. One of the barren cows had been disposed of, and one of the late calvers had dried off completely. The quantity of milk yielded by these three cows was only 8 to 10 quarts daily, and the feed was the same as that given to the two freshly calved cows, except that, as the yield of milk was lower, only 3 to 4 pounds of the mixed corn and cake were given. The three cows consisted of one cross-bred dairy Shorthorn, one Alderney-Ayrshire, and one Welsh-Shorthorn cross. The two samples of milk were churned separately in the laboratory and the butter examined, with the following results :

\begin{tabular}{|c|c|c|c|}
\hline & & $\begin{array}{l}\text { Milk from Freshly } \\
\text { Calved Cows taken on } \\
\text { the Morning of } \\
\text { February } 23 .\end{array}$ & $\begin{array}{l}\text { Milk from Barren Cow } \\
\text { and Late Calvers } \\
\text { drawn on Morning } \\
\text { of February } 23 .\end{array}$ \\
\hline Reichert-Wollny figure & , & $\ldots \quad 36 \cdot 3$ & $19 \cdot 8^{\circ}$ \\
\hline Iodine number & $\ldots$ & $36 \cdot 9$ & $38 \cdot 2$ \\
\hline
\end{tabular}

On March 13 I received from the farm three samples of butter-one from the milk of the same cows which on the previous occasion were described as freshly calved, one a sample of whey butter from the whole of the cows then in milk, and the third a sample made from a mixture of whey cream and "beestings." These yielded the following results :

$\begin{array}{llccc} & & \begin{array}{c}\text { Recently } \\ \text { Calved } \\ \text { Cows. }\end{array} & \begin{array}{c}\text { Whey Butter } \\ \text { from All } \\ \text { Cows. }\end{array} & \begin{array}{c}\text { Butter from Whey } \\ \text { Cream and } \\ \text { "Beestings." }\end{array} \\ \text { Reichert-Wollny figure } & \ldots & 34 \cdot 4 & 30 \cdot 4 & 30 \cdot 9 \\ \text { Iodine number } \ldots & \ldots & 39 \cdot 9 & 38 \cdot 4 & 36 \cdot 9 \\ \text { Saponification value } & \ldots & 224 \cdot 0 & 224 \cdot 0 & 226 \cdot 8\end{array}$

Another sample of butter produced on April 4, 1909, from the mixed morning and evening milk from thirty cows, gave a Reichert-Wollny figure of $29 \cdot 4$.

The conclusion I came to was that, taking into account the whole of the circumstances, the abnormality appeared to be due to the lateness of the period of lactation, and not to bad condition of the cows, such as might have been brought about by defective feeding.

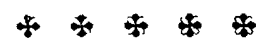

